\title{
Front Matter: Volume 9701
}

, "Front Matter: Volume 9701," Proc. SPIE 9701, Multimodal Biomedical Imaging XI, 970101 (6 May 2016); doi: 10.1117/12.2229258

SPIE. Event: SPIE BiOS, 2016, San Francisco, California, United States 


\section{PROGRESS IN BIOMEDICAL OPTICS AND IMAGING}

\section{Multimodal Biomedical Imaging XI}

Fred S. Azar

Xavier Intes

Editors

13 February 2016

San Francisco, California, United States

Sponsored and Published by

SPIE 
The papers in this volume were part of the technical conference cited on the cover and title page. Papers were selected and subject to review by the editors and conference program committee. Some conference presentations may not be available for publication. Additional papers and presentation recordings may be available online in the SPIE Digital Library at SPIEDigitallibrary.org.

The papers reflect the work and thoughts of the authors and are published herein as submitted. The publisher is not responsible for the validity of the information or for any outcomes resulting from reliance thereon.

Please use the following format to cite material from these proceedings:

Author(s), "Title of Paper," in Multimodal Biomedical Imaging XI, edited by Fred S. Azar,

Xavier Intes, Proceedings of SPIE Vol. 9701 (SPIE, Bellingham, WA, 2016) Six-digit Article CID Number.

ISSN: 1605-7422

ISSN: $2410-9045$ (electronic)

ISBN: 9781628419351

Published by

SPIE

P.O. Box 10, Bellingham, Washington 98227-0010 USA

Telephone +1 3606763290 (Pacific Time) · Fax +1 3606471445

SPIE.org

Copyright @ 2016, Society of Photo-Optical Instrumentation Engineers.

Copying of material in this book for internal or personal use, or for the internal or personal use of specific clients, beyond the fair use provisions granted by the U.S. Copyright Law is authorized by SPIE subject to payment of copying fees. The Transactional Reporting Service base fee for this volume is $\$ 18.00$ per article (or portion thereof), which should be paid directly to the Copyright Clearance Center (CCC), 222 Rosewood Drive, Danvers, MA 01923. Payment may also be made electronically through CCC Online at copyright.com. Other copying for republication, resale, advertising or promotion, or any form of systematic or multiple reproduction of any material in this book is prohibited except with permission in writing from the publisher. The CCC fee code is $1605-$ $7422 / 16 / \$ 18.00$.

Printed in the United States of America.

Publication of record for individual papers is online in the SPIE Digital Library.

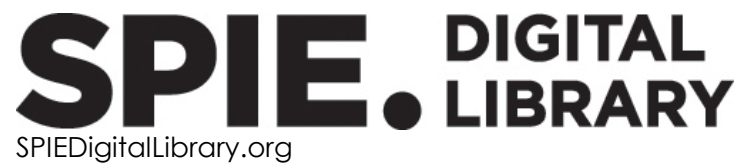

Paper Numbering: Proceedings of SPIE follow an e-First publication model. A unique citation identifier (CID) number is assigned to each article at the time of publication. Utilization of CIDs allows articles to be fully citable as soon as they are published online, and connects the same identifier to all online and print versions of the publication. SPIE uses a six-digit CID article numbering system structured as follows:

- The first four digits correspond to the SPIE volume number.

- The last two digits indicate publication order within the volume using a Base 36 numbering system employing both numerals and letters. These two-number sets start with $00,01,02,03,04$, 05, 06, 07, 08, 09, OA, OB ... 0Z, followed by 10-1Z, 20-2Z, etc. The CID Number appears on each page of the manuscript. 


\title{
Contents
}

\author{
$\checkmark \quad$ Authors \\ vii Conference Committee \\ ix Introduction
}

\section{SESSION $1 \quad$ INSTRUMENT/ALGORITHMS}

970104 Common reduced spaces of representation applied to multispectral texture analysis in cosmetology [9701-3]

970106 Deformable medical image registration of pleural cavity for photodynamic therapy by using finite-element based method [9701-5]

\section{SESSION 2 MULTIMODALITY MICROSCOPY}

$9701 \mathrm{OB} \quad$ Towards in vivo laser coagulation and concurrent optical coherence tomography through double-clad fiber devices [9701-10]

\section{SESSION 3 CLINICAL APPLICATIONS}

9701 OE In vivo detection of cervical intraepithelial neoplasia by multimodal colposcopy [9701-13]

9701 OF Towards multimodal detection of melanoma thickness based on optical coherence tomography and optoacoustics [9701-14]

$9701 \mathrm{OH} \quad$ Multimodal imaging of ocular surface of dry eye subjects [9701-16]

\section{SESSION 4 PRECLINICAL/HYBRID IMAGING}

9701 0J Multi-projection bioluminescence tomography guided system for small animal radiation research platform (SARRP) [9701-18]

$9701 \mathrm{OL} \quad$ Thermal Outlining using Focused Ultrasound (TOFU) with reversible temperature sensitive fluorescent probes [9701-20]

\section{POSTER SESSION}

$97010 Q \quad$ Random laser illumination: an ideal source for biomedical polarization imaging? [9701-25] 
9701 OR Direct reconstruction of pharmacokinetic parameters in dynamic fluorescence molecular tomography by the augmented Lagrangian method [9701-26]

9701 OS Advancing a smart air cushion system for preventing pressure ulcers using projection Moiré for large deformation measurements [9701-27]

9701 OT Fabrication of Indocyanine Green and $2 \mathrm{H}, 3 \mathrm{H}$-perfluoropentane loaded microbubbles for fluorescence and ultrasound imaging [9701-28]

9701 OU Cross-calibrating interferon-Y detection by using eletrochemical impedance spectroscopy and paraboloidal mirror enabled surface plasmon resonance interferometer [9701-29]

9701 OV Adaptive selection of minimally correlated data for optimization of source-detector configuration in diffuse optical tomography [9701-30]

$97010 \mathrm{X}$ Combined optical coherence tomography and hyper-spectral imaging using a double clad fiber coupler [9701-32]

9701 OY Quantitative modulated imaging of turbid media in the high spatial frequency domain [9701-33]

970111 Photoplethysmographic imaging via spectrally demultiplexed erythema fluctuation analysis for remote heart rate monitoring [9701-36]

970112 Non-contact hematoma damage and healing assessment using reflectance photoplethysmographic imaging [9701-37]

970113 Spectral photoplethysmographic imaging sensor fusion for enhanced heart rate detection [9701-38]

970115 Time-resolved hyperspectral single-pixel camera implementation for compressive widefield fluorescence lifetime imaging [9701-40]

970116 Sparse temporal sampling for fast time-domain wide-field fluorescence molecular tomography [9701-41]

970117 Gate-width impact on NIR FRET lifetime fitting using gated ICCD [9701-42] 
Proc. of SPIE Vol. $9701970101-6$

Downloaded From: https://www.spiedigitallibrary.org/conference-proceedings-of-spie on 26 Apr 2023 Terms of Use: https://www.spiedigitallibrary.org/terms-of-use 


\section{Conference Committee}

Symposium Chairs

James G. Fujimoto, Massachusetts Institute of Technology

(United States)

R. Rox Anderson, Wellman Center for Photomedicine, Massachusetts General Hospital (United States) and Harvard School of Medicine (United States)

Program Track Chairs

Tuan Vo-Dinh, Fitzpatrick Institute for Photonics, Duke University (United States)

Anita Mahadevan-Jansen, Vanderbilt University (United States)

Conference Chairs

Fred S. Azar, Philips Medical Systems (United States)

Xavier Intes, Rensselaer Polytechnic Institute (United States)

Conference Program Committee

Caroline Boudoux, Ecole Polytechnique de Montréal (Canada)

Christophe Chefd'hotel, Ventana Medical Systems, Inc.

(United States)

Yu Chen, University of Maryland, College Park (United States)

Qianqian Fang, Massachusetts General Hospital (United States)

Sergio Fantini, Tufts University (United States)

Gultekin Gulsen, University of California, Irvine (United States)

Theodore J. Huppert, University of Pittsburgh (United States)

Tim Nielsen, Philips Research (Germany)

Vasilis Ntziachristos, Helmholtz Zentrum München GmbH (Germany)

Brian W. Pogue, Thayer School of Engineering at Dartmouth

(United States)

Siavash Yazdanfar, GE Global Research (United States)

Arjun G. Yodh, University of Pennsylvania (United States)

\section{Session Chairs}

1 Instrument/Algorithms

Xavier Intes, Rensselaer Polytechnic Institute (United States)

Fred S. Azar, Philips Medical Systems (United States) 
2 Multimodality Microscopy

Caroline Boudoux, Ecole Polytechnique de Montréal (Canada)

Fred S. Azar, Philips Medical Systems (United States)

3 Clinical Applications

Caroline Boudoux, Ecole Polytechnique de Montréal (Canada)

Fred S. Azar, Philips Medical Systems (United States)

4 Preclinical/Hybrid Imaging

Gultekin Gulsen, Center for Functional Onco-Imaging (United States)

Xavier Intes, Rensselaer Polytechnic Institute (United States) 


\section{Introduction}

Optical techniques offer the potential to contribute greatly to the expansion of clinical multimodality techniques. Their ability to image structural, functional, and molecular information at different spatial and temporal scales makes them very attractive to the biomedical community. There is critical need for new instrumental approaches and computational techniques to provide rapid, accurate and costeffective means for acquisition, quantification and characterization of multimodal data. Multimodality approach can be understood as the combination of multiple optical techniques in an instrument and/or fusion of an optical technique with other well-established imaging modalities such as CT, MRI, US, or PET. These instrumental and computational methods will enable faster acceptance of novel imaging modalities into viable clinical and/or pre-clinical systems. The applications are diverse and range from imaging at the cellular level to the whole body while incorporating molecular, functional and anatomical information.

The conference objectives are to provide a forum:

- to review and share recent developments in novel multimodal imaging techniques,

- to report development of novel computational methods, and

- to bring together the optical imaging and image analysis communities.

Topics include, but are not limited to:

- Multimodal imaging integrating structural, molecular and functional information

- Multimodal microscopic imaging

- 2D, 3D, 4D tomographic and / or multi-spectral imaging

- Imaging analysis and/or image processing techniques applied to optical imaging (e.g. visualization, segmentation, registration)

- Multimodal imaging instrumentation and system design

- Detection and diagnostic analysis techniques which may provide better quantitative and/or diagnostic insight into clinical and pre-clinical imaging (e.g. methods for quantitative measurements, computer-assisted diagnosis)

- Imaging analysis and/or image processing techniques used to combine optical imaging with other imaging modalities (e.g. MR, x-ray, PET)

- Image analysis, computational methods and reconstruction approaches which may help bring optical imaging into the clinic (visual rendering of complex data set, novel algorithms for assisted optical reconstruction)

- Clinical evaluation of these new technologies (physiological and functional interpretation of image data, visual perception and observer performances, validation of quantitative assessment of optical signatures in-vivo).

Fred S. Azar

Xavier Intes 
Proc. of SPIE Vol. $9701970101-10$

Downloaded From: https://www.spiedigitallibrary.org/conference-proceedings-of-spie on 26 Apr 2023 Terms of Use: https://www.spiedigitallibrary.org/terms-of-use 